Journal of Engineering and Applied Sciences 14 (15): 5241-5249, 2019

ISSN: 1816-949X

(C) Medwell Journals, 2019

\title{
Scouring Around Impermeable Curved Groynes
}

\author{
${ }^{1}$ Saleh I. Khassaf and ${ }^{2}$ Hiba A. Abbas \\ ${ }^{1}$ Department of Civil, College of Engineering, University of Basrah, Basrah, Iraq \\ salehissakh@gmail.com,07806768085 \\ ${ }^{2}$ Department of Civil, College of Engineering, University of Kufa, Kufa, Iraq \\ hiba.abbas@uokufa.edu.iq,07816032919
}

\begin{abstract}
Groynes are ban impressive engineered methods that used to diverge the flow away from the banks to protect them from erosion, control the flood situations, improve the navigation and also decrease rivers dredging costs, since, their presence will regulate and increase the sediments transport rate through the river reach at the groynes location. In spite of the many advantages for construction the groynes but their presence lead to develop the local scour phenomena which in time cause a structural failure to the groynes body. This issue presents a need to find solutions that have the ability to lessen the scour process along with maintaining all the above benefits of the groynes. The present study introduced a creative solution which is using groynes having a C-shape that have the ability to reduce the scour around themselves through smoothing the water streamlines paths as much as possible to cause little disturbance and hence, less scour. Also the C-shape groynes are compared with the I-shape groynes. The number of groynes is studied also as a countermeasure for more reducing to the local scour phenomena. The study was performed through a laboratory flume with bed material having a median size $\left(\mathrm{d}_{50}\right)$ equal to $(0.7 \mathrm{~mm})$. A polystyrene foam material was used to manufacture the physical models where they investigated under clear water conditions and steady subcritical flow. The results showed that using the C-shape groynes instead of the I-shape groynes for the same hydraulic conditions will reduce the maximum local scour depth with a great percentage. Based on the experimental data, an empirical formula that give good agreement between the observed results experimentally and the predicted ones from it were derived.
\end{abstract}

Key words: Local scouring, C-shape groynes, clear water conditions, maximum scour depth, bank erosion, I-shape groynes

\section{INTRODUCTION}

Groynes are an artificial flow deflecting structures, generally utilized directly or indirectly in river engineering to control meandering of rivers and to hinder the banks erosion. They also serve many additional purposes such as enhancing aquatic habitats through making low velocity pools around them, so, fish can feed and rest, improving the navigability of channels by providing sufficient flow depth and offering safety to the important hydraulic structures. These structures are typically constructed from different materials such as piles, Earth, rock, gravel or stone and starting with a root at the river bank and terminating with a head at the regulation line. Depending on the design conditions, groynes can be designed either submerged or non-submerged. Since, flow over the top of the impermeable groynes may create severe erosion, so, they designed as non-submerged

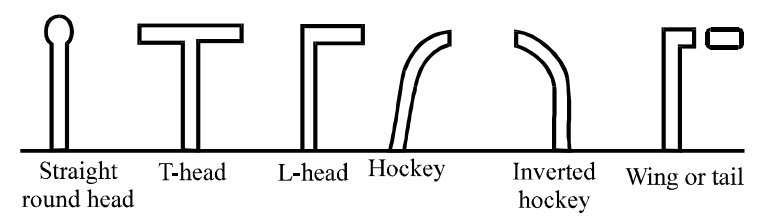

Fig. 1: Different shapes of groynes

ones. Groynes have different shapes in the plan view appearance, i.e., I-shape, L-shape, hockey and inverted hockey shape (Fig. 1).

The presence of groynes through a river reach create unique flow situation, since, they will confine specific part of the cross section of the river, this scenario have great influence on the flow kinematic structure in the vicinity of these groynes (Dehghani et al., 2013). So, in the groynes location the flow will constrict and the mean velocity as well as the specific discharge increase, consequently, the

Corresponding Author: Saleh I. Khassaf, Department of Civil, College of Engineering, University of Basrah, Basrah, Iraq salehissakh@gmail.com, 07806768085 
flow will diverges towards the bed sediments, resulting in formation the scour holes around the groynes themselves. In general, the scour is natural phenomenon originated due to the water flow in streams and rivers where this flow cause erosive action that erodes and takes away sediments material from the banks, bed and also from the nearby areas of abutments, groynes and bridge piers. The above described mechanism of scour has the long term capability to endanger the groynes and other hydraulic structures to structural failure after undermining their foundations (Masjedi et al., 2010).

During the groynes design phase, the scour nearby them is the most important factor that has to be considered. The maximum depth of scouring is consider crucial indicator in setting the scouring specifications and establishing its expanding range and position, so, estimation this depth has been the principal concern for engineers over the years, since, its often taken as the design depth during the foundation design phase of groynes. Since, the straight (I-shape) groynes are the simplest case of groynes layout, so, most of the previous investigations had concerned in prediction the maximum equilibrium scour depth around these groynes such as Ahmad (1953), Gill (1972), Melville (1997), Barbhuiya and Dey (2003), Onda et al. (2007) and Yossef and de Vriend (2010). The present study is consider vital one because it highlights the huge benefits of using curved shape groynes through making a comparison between them and the straight shape groynes, this study will show how using curved groynes leads to less scour at their heads, larger deposits of sediment between them and greater protection to the river banks. Also, using number of groynes as a sort of countermeasure for more lessen to the scour around the curved groynes is investigated in this study.

\section{MATERIALS AND METHODS}

The complicated phenomenon of scour around groynes is influenced by number of factors, these factors were reported by Lagasse and Richardson (2001) they grouped as:

- Factors connected to the approaching flow conditions: bed roughness, mean and shear velocity, velocity distribution, flow depth and velocity

- Factors connected to the bed sediment: particles shape, particles size distribution, particles mass density, coherence of soil and angle of repose

- Factors connected to the groynes: orientation, length, spacing, plan view shape and number of groynes

- Factors connected to the fluid properties: gravitational acceleration, kinematic viscosity and the mass density
All the above factors are processed utilizing dimensional analysis which is mathematical technique used for design and performing models experiments. So, the maximum scour depth $\left(\mathrm{ds}_{\mathrm{max}}\right)$ for clear water conditions are written in the functional form as:

$$
\mathrm{ds}_{\max }=\mathrm{f}\left\{\mathrm{y}, \mathrm{v}, \mathrm{vc}, \mathrm{L}, \rho, \rho \mathrm{s}, \mathrm{g}, \mathrm{n}, \mathrm{b}, \mathrm{d}_{50}, \mu, \sigma_{\mathrm{g}}, \mathrm{B}, \mathrm{s}_{0}\right\}
$$

Where:

$\begin{array}{ll}\mathrm{y} & =\text { Depth of flow } \\ \mathrm{v} \text { and } \mathrm{vc} & =\text { The main flow and the critical velocities } \\ \rho \text { and } \rho \mathrm{s} & =\text { Fluid and bed sediments densities } \\ \mathrm{g} & =\text { Gravitational acceleration } \\ \mathrm{n} & =\text { Groynes number } \\ \mathrm{d}_{50} & =\text { Median grain size } \\ \mathrm{L} & =\text { Groynes length } \\ \mathrm{b} & =\text { Spacing between groynes } \\ \mu & =\text { The fluid dynamic viscosity } \\ \sigma_{\mathrm{g}} & =\text { Geometric standard deviation } \\ \mathrm{B} & =\text { The experimental flume width } \\ \mathrm{S}_{0} & =\text { The flume slope }\end{array}$

Using one of the dimensional analysis methods, i.e., the Buckingham's $\pi$ theorem and after few simplifications, the above equation for the curved shape groyne that had been studied in this study can be written to include only the investigated parameters as:

$$
\mathrm{ds}_{\max } / \mathrm{y}=\mathrm{f}(\mathrm{v} / \mathrm{vc}, \mathrm{Fr}, \mathrm{n})
$$

All the tested parameters data along with the final results are listed in Table 1.

Experimental work: All experiments of this study were conducted in flume made by the researcher (Fig. 2). The basic frame of the flume was metal with tempered glass sides with a total length of $(7.225 \mathrm{~m})$ and inner section of $\left(0.4^{*} 0.4 \mathrm{~m}\right)$. The flume is divided to three parts, the first part is the inlet tank that located in the flume upstream and supplying water to the working section part of the flume, this first part having dimensions of $\left(1^{*} 0.6^{*} 0.4 \mathrm{~m}\right)$ for length, depth and width respectively. Two screens are placed inside the inlet tank to prevent any debris or unwanted particles from entering to the working section that represents the flume second part with total length of (5.025).

For better understanding, the second part is separated to three sections. The first section, contains sharp crested rectangular weir utilized for discharge measuring with dimensions of $\left(0.4^{*} 0.25 \mathrm{~m}\right)$ to width and height, respectively. The middle section is filled with 
J. Eng. Applied Sci., 14 (15): 5241-5249, 2019

Table 1: The experimental data and the final results

\begin{tabular}{|c|c|c|c|c|c|c|c|c|c|}
\hline Run number & Model name & $\mathrm{Y}(\mathrm{mm})$ & $\mathrm{v}(\mathrm{m} / \mathrm{sec})$ & $\mathrm{vc}(\mathrm{m} / \mathrm{sec})$ & $\mathrm{N}$ & $\mathrm{Fr}$ & $\mathrm{v} / \mathrm{vc}$ & $\mathrm{ds}(\mathrm{mm})$ & $\mathrm{ds} / \mathrm{y}$ \\
\hline 1 & I-shape & 21 & 0.2220 & 0.2436 & 1 & 0.4900 & 0.91130 & 45 & 2.14 \\
\hline 2 & I-shape & 21 & 0.1981 & 0.2436 & 1 & 0.4364 & 0.81320 & 41 & 1.95 \\
\hline 3 & I-shape & 21 & 0.1752 & 0.2436 & 1 & 0.3860 & 0.71937 & 34 & 1.62 \\
\hline 4 & I-shape & 21 & 0.1514 & 0.2436 & 1 & 0.3336 & 0.62156 & 25 & 1.19 \\
\hline 5 & I-shape & 46 & 0.1800 & 0.2810 & 1 & 0.2680 & 0.64057 & 71 & 1.5434 \\
\hline 6 & I-shape & 36 & 0.1800 & 0.2700 & 1 & 0.3030 & 0.66840 & 55 & 1.52778 \\
\hline 7 & I-shape & 26 & 0.1800 & 0.2540 & 1 & 0.3564 & 0.70920 & 39 & 1.5 \\
\hline 8 & I-shape & 16 & 0.1800 & 0.2307 & 1 & 0.4540 & 0.78030 & 10 & 0.625 \\
\hline 9 & I-shape & 21 & 0.2220 & 0.2436 & 2 & 0.4900 & 0.91130 & 36 & 1.71 \\
\hline 10 & I-shape & 21 & 0.1981 & 0.2436 & 2 & 0.4364 & 0.81320 & 31 & 1.47619 \\
\hline 11 & I-shape & 21 & 0.1752 & 0.2436 & 2 & 0.3860 & 0.71937 & 22 & 1.047619 \\
\hline 12 & I-shape & 21 & 0.1514 & 0.2436 & 2 & 0.3336 & 0.62156 & 3 & 0.142857 \\
\hline 13 & I-shape & 46 & 0.1800 & 0.2810 & 2 & 0.2680 & 0.64057 & 62 & 1.347826 \\
\hline 14 & I-shape & 36 & 0.1800 & 0.2700 & 2 & 0.3030 & 0.66840 & 43 & 1.1944 \\
\hline 15 & I-shape & 26 & 0.1800 & 0.2540 & 2 & 0.3564 & 0.70920 & 31 & 1.192307 \\
\hline 16 & I-shape & 16 & 0.1800 & 0.2307 & 2 & 0.4540 & 0.78030 & 0 & 0 \\
\hline 17 & I-shape & 21 & 0.2220 & 0.2436 & 3 & 0.4900 & 0.91130 & 29 & 1.38095 \\
\hline 18 & I-shape & 21 & 0.1981 & 0.2436 & 3 & 0.4364 & 0.81320 & 25 & 1.190476 \\
\hline 19 & I-shape & 21 & 0.1752 & 0.2436 & 3 & 0.3860 & 0.71937 & 16 & 0.7619 \\
\hline 20 & I-shape & 21 & 0.1514 & 0.2436 & 3 & 0.3336 & 0.62156 & 0 & 0 \\
\hline 21 & I-shape & 46 & 0.1800 & 0.2810 & 3 & 0.2680 & 0.64057 & 55 & 1.19565 \\
\hline 22 & I-shape & 36 & 0.1800 & 0.2700 & 3 & 0.3030 & 0.66840 & 36 & 1 \\
\hline 23 & I-shape & 26 & 0.1800 & 0.2540 & 3 & 0.3564 & 0.70920 & 25 & 0.961538 \\
\hline 24 & I-shape & 16 & 0.1800 & 0.2307 & 3 & 0.4540 & 0.78030 & 0 & 0 \\
\hline 25 & C-shape & 21 & 0.2220 & 0.2436 & 1 & 0.4900 & 0.91130 & 21 & 1 \\
\hline 26 & C-shape & 21 & 0.1981 & 0.2436 & 1 & 0.4364 & 0.81320 & 18 & 0.8571 \\
\hline 27 & C-shape & 21 & 0.1752 & 0.2436 & 1 & 0.3860 & 0.71937 & 10 & 0.4762 \\
\hline 28 & C-shape & 21 & 0.1514 & 0.2436 & 1 & 0.3336 & 0.62156 & 0 & 0 \\
\hline 29 & C-shape & 46 & 0.1800 & 0.2810 & 1 & 0.2680 & 0.64057 & 32 & 0.6956 \\
\hline 30 & C-shape & 36 & 0.1800 & 0.2700 & 1 & 0.3030 & 0.66840 & 21 & 0.58333 \\
\hline 31 & C-shape & 26 & 0.1800 & 0.2540 & 1 & 0.3564 & 0.70920 & 15 & 0.576923 \\
\hline 32 & C-shape & 16 & 0.1800 & 0.2307 & 1 & 0.4540 & 0.78030 & 0 & 0 \\
\hline 33 & C-shape & 21 & 0.2220 & 0.2436 & 2 & 0.4900 & 0.91130 & 11 & 0.5238 \\
\hline 34 & C-shape & 21 & 0.1981 & 0.2436 & 2 & 0.4364 & 0.81320 & 8 & 0.38095 \\
\hline 35 & C-shape & 21 & 0.1752 & 0.2436 & 2 & 0.3860 & 0.71937 & 6 & 0.2857 \\
\hline 36 & C-shape & 21 & 0.1514 & 0.2436 & 2 & 0.3336 & 0.62156 & 0 & 0 \\
\hline 37 & C-shape & 46 & 0.1800 & 0.2810 & 2 & 0.2680 & 0.64057 & 14 & 0.347826 \\
\hline 38 & C-shape & 36 & 0.1800 & 0.2700 & 2 & 0.3030 & 0.66840 & 12 & 0.333 \\
\hline 39 & C-shape & 26 & 0.1800 & 0.2540 & 2 & 0.3564 & 0.70920 & 8 & 0.30769 \\
\hline 40 & C-shape & 16 & 0.1800 & 0.2307 & 2 & 0.4540 & 0.78030 & 0 & 0 \\
\hline 41 & C-shape & 21 & 0.2220 & 0.2436 & 3 & 0.4900 & 0.91130 & 7 & 0.3333 \\
\hline 42 & C-shape & 21 & 0.1981 & 0.2436 & 3 & 0.4364 & 0.81320 & 3 & 0.142857 \\
\hline 43 & C-shape & 21 & 0.1752 & 0.2436 & 3 & 0.3860 & 0.71937 & 2 & 0.095238 \\
\hline 44 & C-shape & 21 & 0.1514 & 0.2436 & 3 & 0.3336 & 0.62156 & 0 & 0 \\
\hline 45 & C-shape & 46 & 0.1800 & 0.2810 & 3 & 0.2680 & 0.64057 & 9 & 0.19565 \\
\hline 46 & C-shape & 36 & 0.1800 & 0.2700 & 3 & 0.3030 & 0.66840 & 7 & 0.1944 \\
\hline 47 & C-shape & 26 & 0.1800 & 0.2540 & 3 & 0.3564 & 0.70920 & 5 & 0.19231 \\
\hline 48 & C-shape & 16 & 0.1800 & 0.2307 & 3 & 0.4540 & 0.78030 & 0 & 0 \\
\hline
\end{tabular}

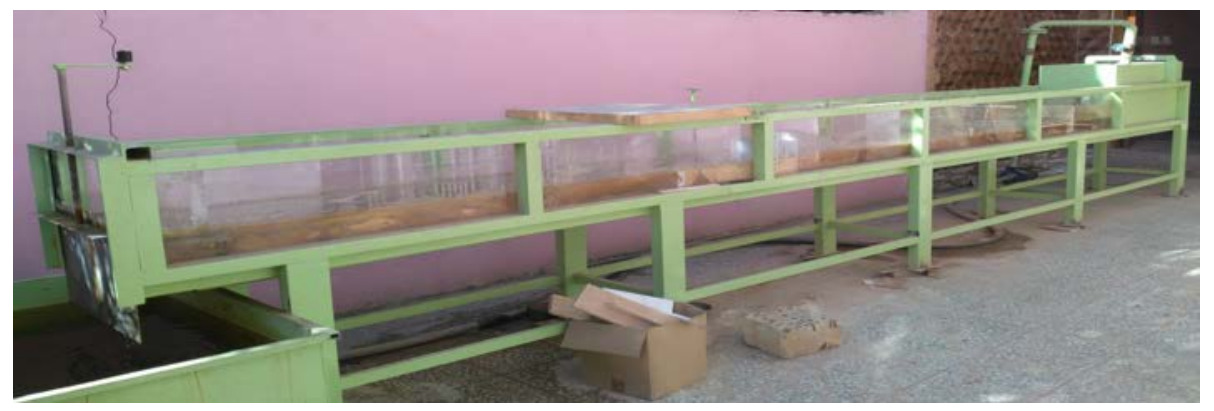

Fig. 2: The laboratory flume

uniform erodible sediments to a depth of $(0.1 \mathrm{~m})$ and extends over $(3 \mathrm{~m})$. The remaining of the second part of the flume was raised to a level of $(0.1 \mathrm{~m})$ using non-swelling compressed wood plates for the purpose of matching the level of the erodible sediments. In the flume end, a metal reservoir with dimensions of $\left(1.2^{*} 1^{*} 0.625 \mathrm{~m}\right)$ 
was placed to supply the water for the flume through closed water system using pump located at the flume upstream.

To control the flow depth within the flume an adjustable tail gate was used where it located at the end of the flume second part. In each run, after its end, the flume was emptied carefully from water and then using scraper, the sand bed is set to be straight again for the next run. All the scour hole measurements were taken using point gauge made manually from metal bar and having a $(0.4 \mathrm{~m})$ length with needle end to facilitate the measurements.

To cover the present study goals and for simulating different practical situations, two groyne shapes which they I- \& C-shape were used (Fig. 3) they made of polystyrene foam material with $(0.01 \mathrm{~m})$ thick, $(0.15 \mathrm{~m})$ height and $(0.13 \mathrm{~m})$ for length. Also, it has been used the groynes in three different configurations (single, double, and triple) to see the effect of changing number of groynes on the scour process. The geometrical dimensions for both models are given in Table 2 .

It should be mentioned that that the used length of the groynes was limited to less than one third the width of the flume as recommended (i.e., $\mathrm{L}=130 / 400=0.325$ ) (Martin, 1995). The spacing between the groynes was fixed to be two times the groynes length. The location of the groynes was chosen to be in the middle of the flume working section to achieve a well established flow where

Table 2: The geometrical dimensions for the models

\begin{tabular}{lllcc}
\hline Model name and number & Shape of groyne (top view) & $\mathrm{L}_{\mathrm{g}}(\mathrm{cm})$ & $\mathrm{I}$ (cm) & Total summation of groynes models \\
\hline 1. I-shape & Flow & & \\
2. C-shape & Flow & & \\
\hline
\end{tabular}

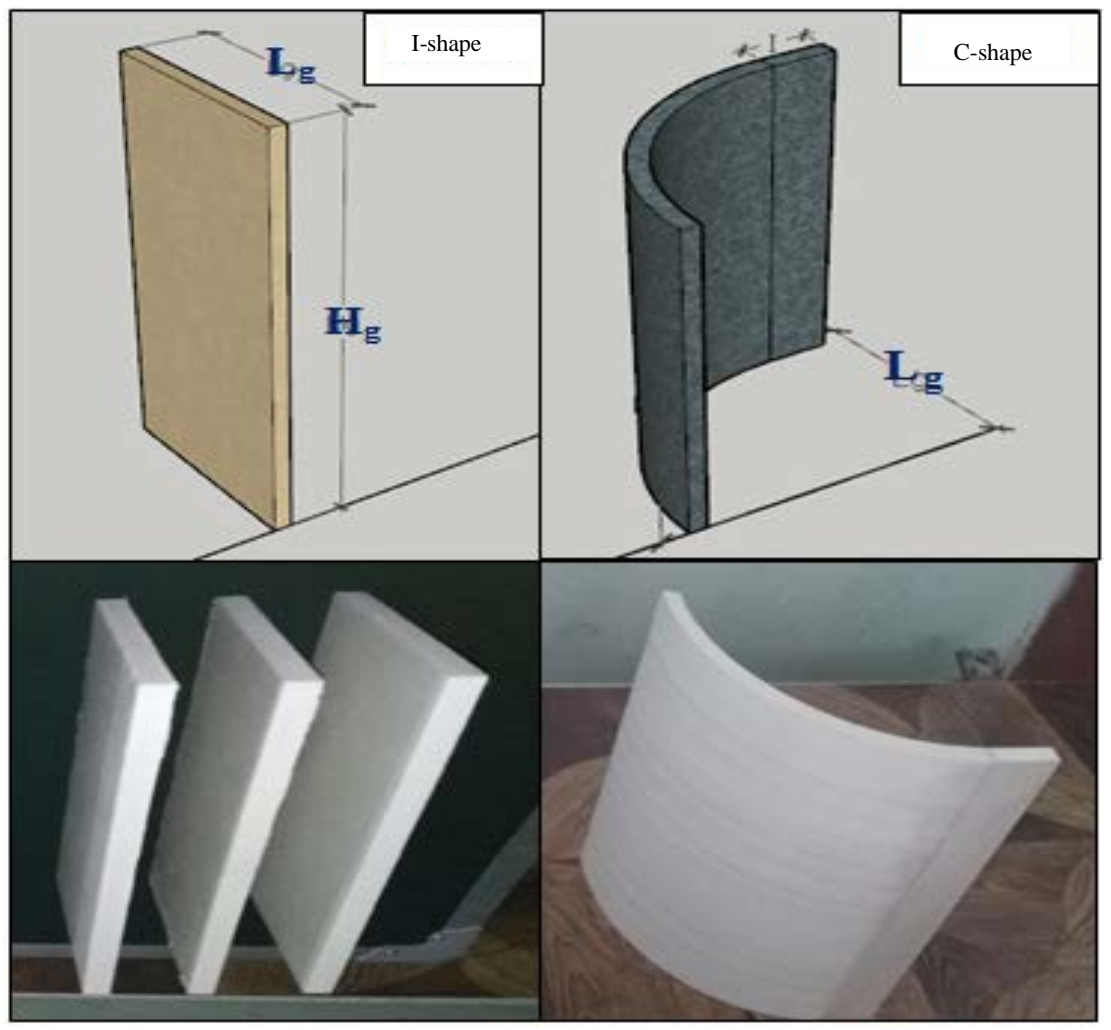

Fig. 3: The I- \& C-shape groyne models 


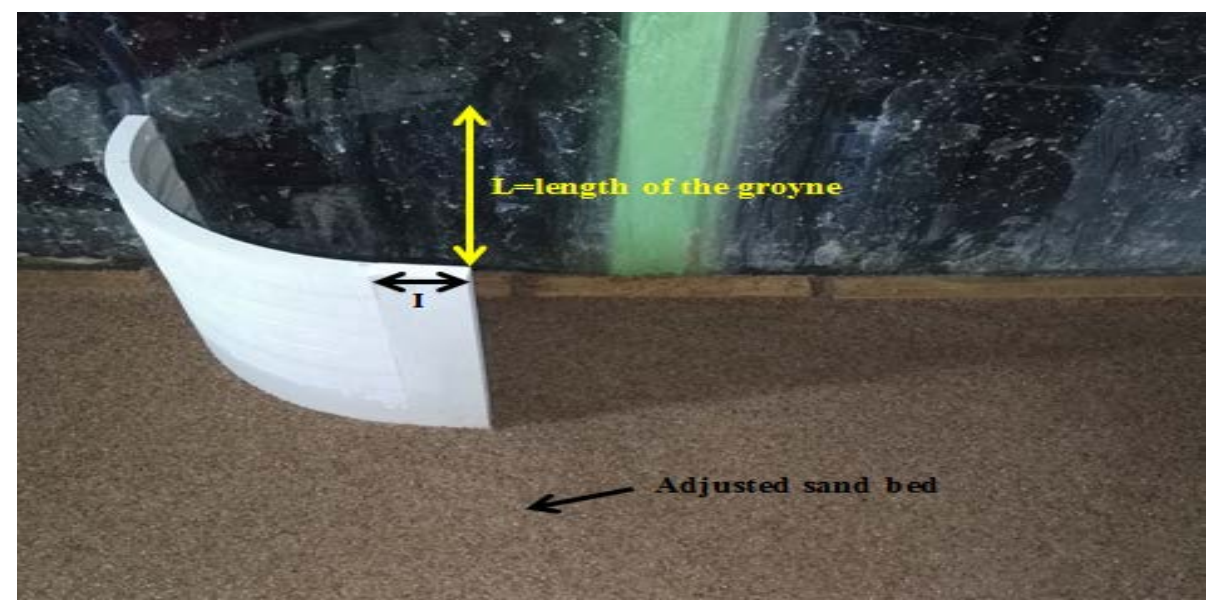

Fig. 4: C-shape groyne placed in the flume

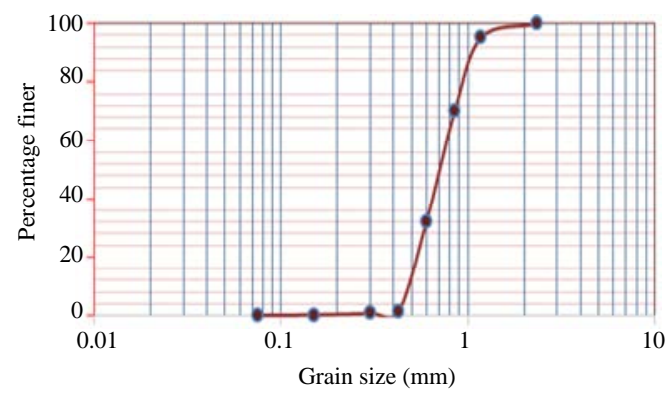

Fig. 5: The bed material grain size distribution $\left(d_{50}=0.7\right.$ $\mathrm{mm}$ )

they fixed vertically in the sand layer through a silicon adhesive that used to stick them promptly to the internal flume side. Figure 4 shows a C-shape groyne fixed inside the flume before beginning the experiments.

As regard the bed flume material, it has been used sand that its characteristics were obtained by mechanical sieve analysis conducted at the quality control laboratory in Kufa University. The grain size distribution results showed the used sand was a cohesion-less having main diameter equal to $\left(\mathrm{d}_{50}=0.7 \mathrm{~mm}\right)$ where this value guaranties that ripple will not be formed, since, they are formed only, if the particles mean diameter larger than $(0.7 \mathrm{~mm})$. Also, to assure that the sediment size will not affect the depth of scour, the value of the geometric standard deviation for the used size of sand was $\sigma_{\mathrm{g}}=1.31$ (Jafari and Masjedi, 2015). Figure 5 illustrates the resulted curve of the grain size distribution.

Since, it is greatly significant to determine the required time to achieve the equilibrium conditions of scour that used in all the experiments, so, four distinctive flow velocities were used and the maximum scour at the groynes upstream nose was measured using point gauge and recorded at different time intervals. The stable

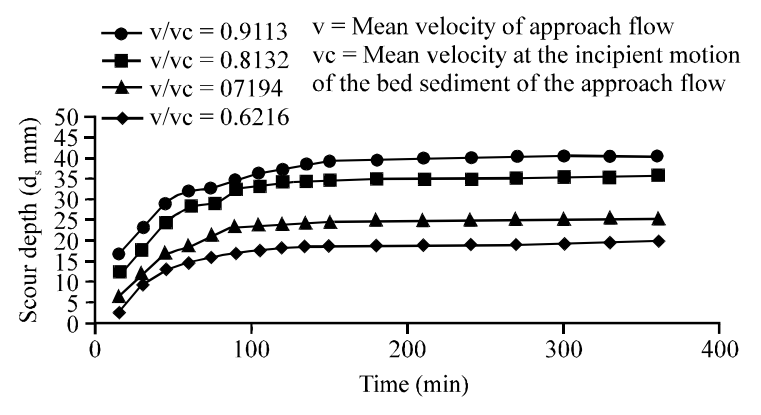

Fig. 6: Scour depth development with the time

conditions of no more scour occurring with increasing time were allowed to be achieved after performing the runs for whole $6 \mathrm{~h}(360 \mathrm{~min})$. The results of the four runs were drawn in Fig. 6. The figure shows increasing the scour depth swiftly during the first half of the run period, after that the resulted curves became nearly flat and the scour depth values were constant through the second half, in another words, it has been noticed that (95-97\%) of the local scour was accomplished in $(3.5 \mathrm{~h})$. So, to eliminate the effect of time and for more accuracy a time period of $(4 \mathrm{~h})$ has been utilized for all experiments in this study. Forty eight experiments were conducted under steady subcritical flow and clear water conditions with flume bed having zero slope to see how the depth of scour affected by the most important parameters which they are shape of the groyne, flow depth (y), flow velocity (v), Froude number $(\mathrm{Fr})$ and number of groynes.

\section{RESULTS AND DISCUSSION}

The following five parts show and discuss the obtained results from the laboratory work regarding the main parameters that have the greatest effect on the scour 

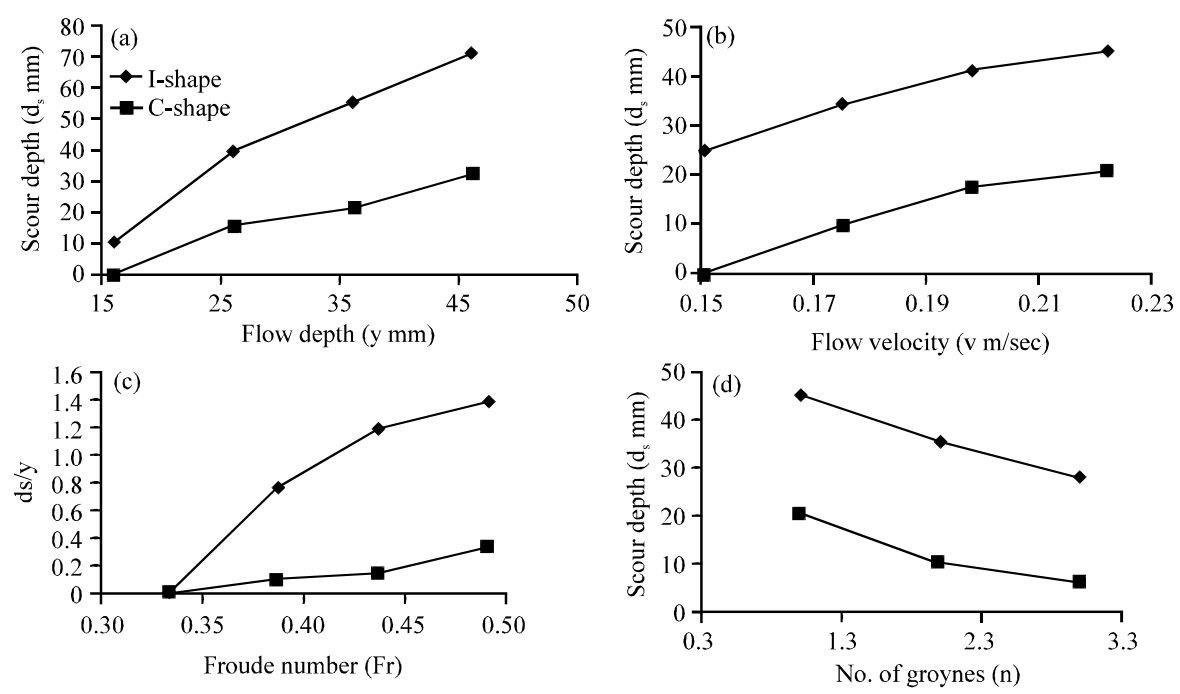

Fig. 7: Development of scouring depths for the two shapes with: a) Flow depth; b) Flow velocity; c) Froude number and d) Number of groynes

phenomenon around groynes and hence on their foundations design process. The sixth part shows developing an equation to calculate the local scour depth using computer package for the C-shape only.

I- \& C-shape groynes comparison: To investigate the effect of using a $\mathrm{C}$-shape groynes rather than using I-shape groynes as clear as possible, these two shapes were studied under the same hydraulic conditions and for the same influencing parameters where in each shape both the flow depth and velocity are changed four times, also the number of groynes have been changed three times (single, double and triple). Figure $7 \mathrm{a}-\mathrm{d}$ relate the maximum scour depth (which is the most lucid dimension that affected by changing the groyne shape) with different groyne shapes for the various parameters that examined in this study.

It is very clear from the above figure that the scouring process follows the same behavior for the two shapes but in the same time the scour holes depth (and hence the volume of the scour holes) is having maximum values when the shape of the groyne is (I-shape) while the minimum values when using the $\mathrm{C}$-shape groynes. The reason for this situation may due to the separation zone length which definitely changes according to shape of groynes. This means, the length of the separation zone for the I-shape groyne is the largest one as compared with the $\mathrm{C}$-shape groyne that will have a minimum separation length. As a result, the return current will be the weakest around the $\mathrm{C}$-shape groyne where this eventually lead to have minimum scour depth caused by it.
From the experimental observations when the groynes has $\mathrm{C}$-shape, then it is so, obvious that this shape has better roundness from the I-shape, so, the flow streamlines will have smooth paths as much as possible. A closer look for the C-shape, it is so, clear that the water flow hits the upstream face, so, gently and takes paths contiguous to the groyne body that bending in a way to cause a very little disturbance around the groyne as a result of putting the groyne itself in this location. Figure 8 shows the resulted scour hole around the I- \& C-shape when the two groynes shapes are examined under the same hydraulic conditions $(\mathrm{v}=0.222 \mathrm{~m} / \mathrm{sec}$, $y=21 \mathrm{~mm}$ and $\mathrm{n}=3$ ) for the above situation using the $\mathrm{C}$-shape groynes instead of the I-shape groyne reduced the maximum scour depth by about $(76 \%)$.

Effect of flow depth on the scour depth: Using different numbers of C-shape groynes to show the effect of changing the flow depth on the scour depth are illustrated in Fig. 9 where it is clearly that the scour happening is directly proportional to the flow depth, i.e., any increase in the flow depth will increase also the scour depth when all other parameters are kept fixed. Comparatively, the surface roller flow became more dominate when the flow depth decreased which that leads to decrease the horse shoe vortices ability to entrain sediments.

Effect of flow velocity on the scour depth: For the velocities that less than the threshold value as the flow velocity increases, the scour depth increase linearly with constant values for all the other influencing parameters. 


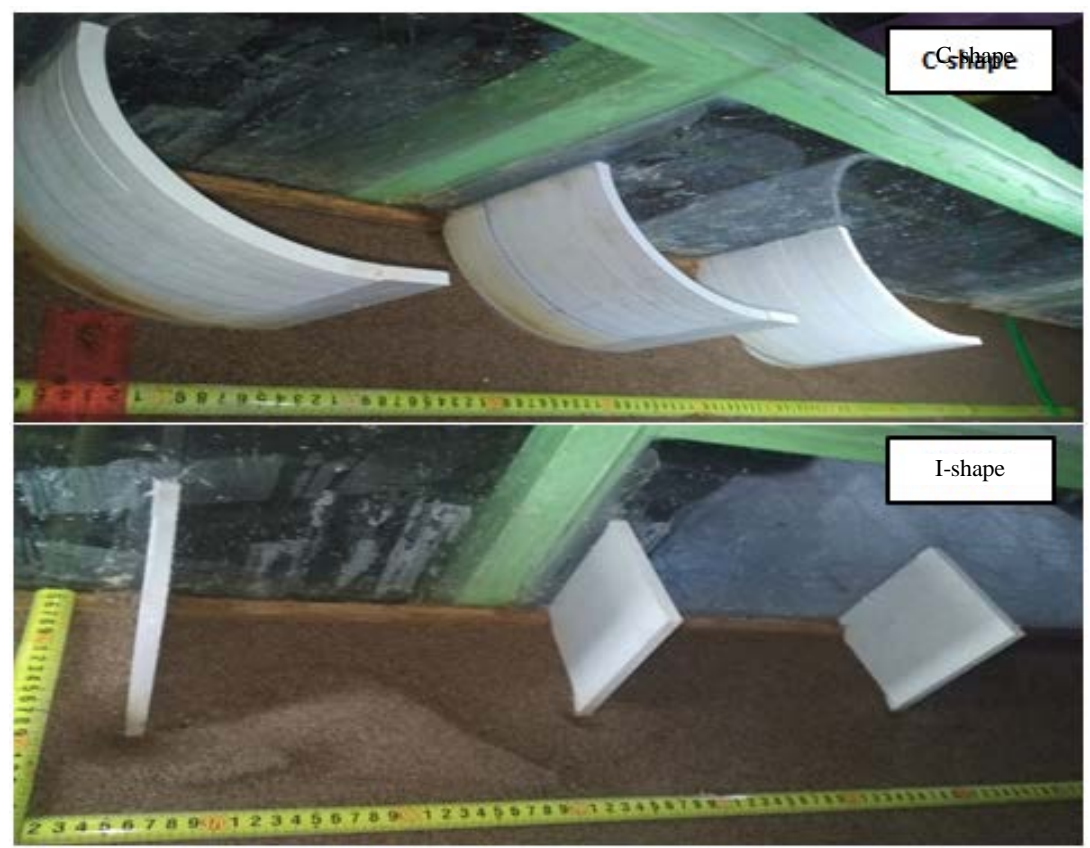

Fig. 8: Effect of groynes shape on the scour depth

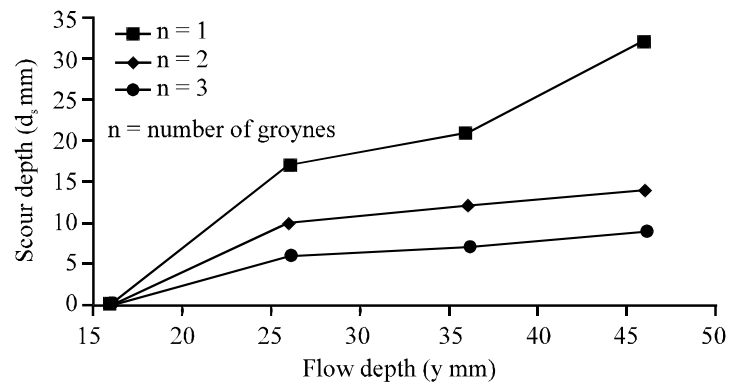

Fig. 9: Effect of flow depth on the scour depth for the C-shape groyne

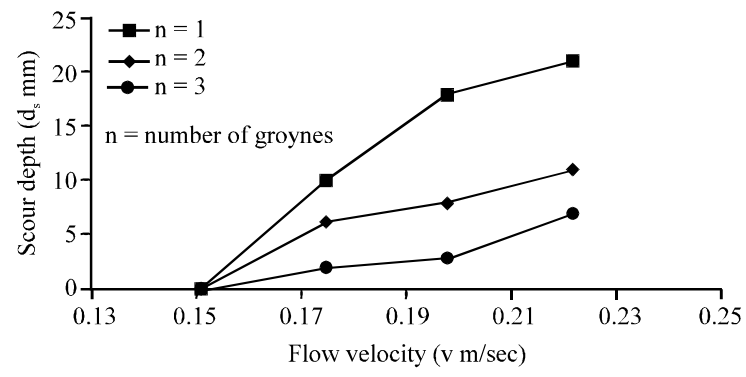

Fig. 10: Effect of flow velocity on the scour depth for the C-shape groyne

This result is showed in Fig. 10 where it can attributed to the fact that increasing the velocity will increase the production of eddies in the groyne downstream due to the enlargement in the separation zone, so that, will cause more scour to occur (Fig. 11).
Effect of Froude number on the scour depth: The obtained results of using C-shape groyne have been drawn in Fig. 12 to show how changing Froude number lead to a major effect on the scour process. The plotted figure shows increasing the scour depth at increasing Froude number where this can be explained perfectly through the law of Froude number $(\mathrm{Fr}=\sqrt{ } \mathrm{v} / \mathrm{gy})$ itself.

Effect of number of groynes on the scour depth: The groynes number has pivotal and instant effect on the scour process and especially the scour depth. With keeping all the influencing parameters constant and changing the groynes configuration three times (single, double and triple) (Fig. 13) is plotted to show how increasing groynes number will decrease the scour depth where the results showed that using three C-shape groynes will decrease the scour depth by about (66.7\%) than using one single C-shape groyne. The presence of successive groynes leads to overlapping the successive vortices, so, their strength will be weakened and that leads to less scour.

Effect of number of groynes on the scour depth: In this study, a computer package (IBM Statistics SPSS 16.0) with a non-linear regression analysis were used to get an equation utilized to find out the relative scour depth $\left(\mathrm{ds}_{\max } / \mathrm{y}\right)$, the results of the laboratory work where used as an input data for the above program: 


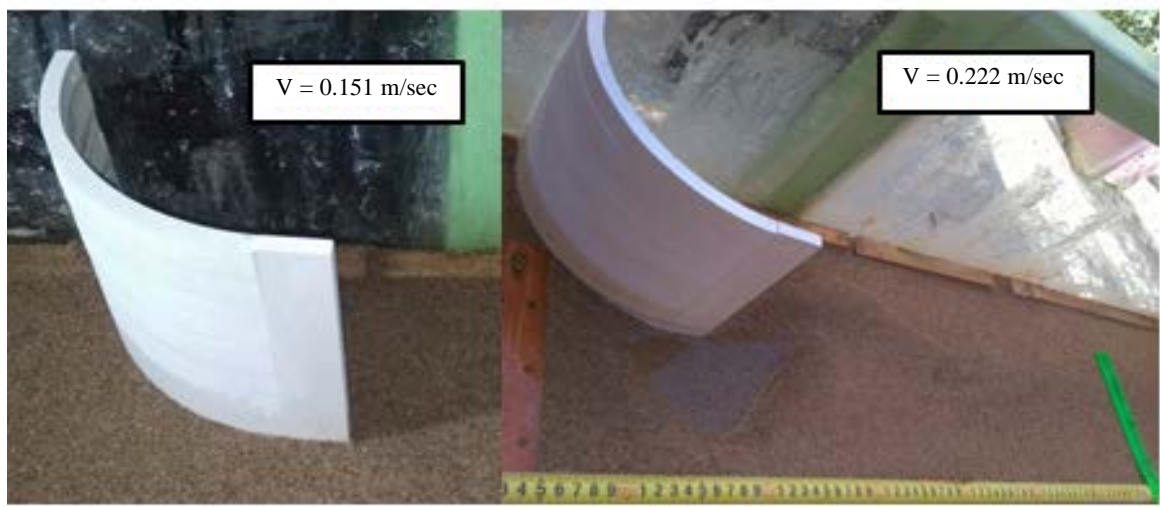

Fig. 11: Flow velocity effect on the scour depth for the C-shape groyne

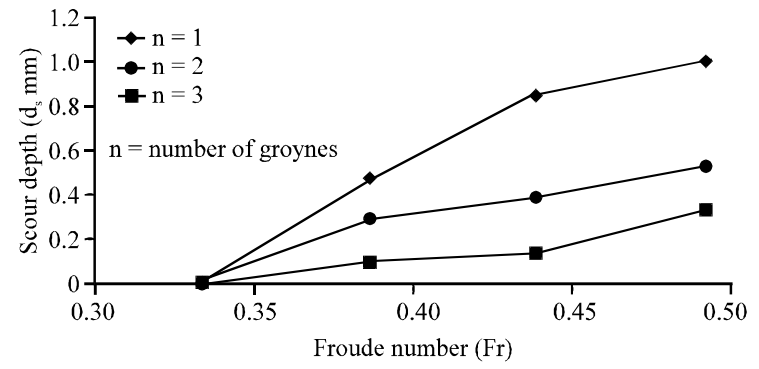

Fig. 12: Froude number effect on the scour depth for the $\mathrm{C}$-shape groyne

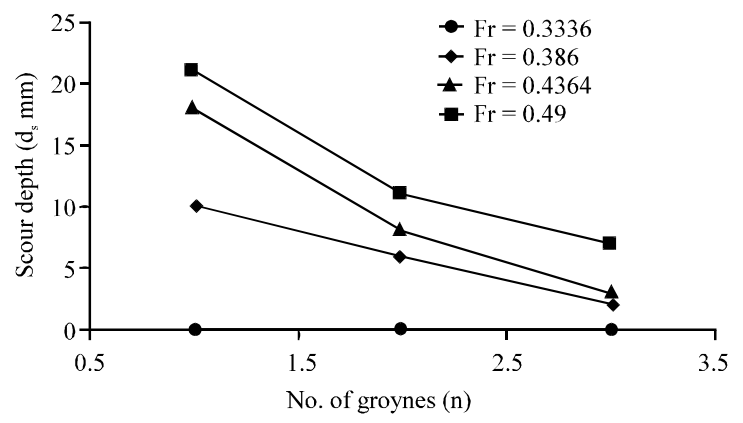

Fig. 13: Number of groynes effect on the scour depth for the $\mathrm{C}$-shape groyne $(\mathrm{Fr}=$ Froude number $)$

$$
\begin{aligned}
& \mathrm{ds}_{\max } / \mathrm{y}=\mathrm{C}_{1}+\left\{\mathrm{C}_{2}{ }^{*}(\mathrm{v} / \mathrm{vc})^{\mathrm{C} 3}\right\}+\left\{\mathrm{C}_{4}{ }^{*}\left(\mathrm{Fr}^{\mathrm{Cs}}\right)\right\}+\mathrm{C}_{6}{ }^{*} \mathrm{n} \\
& \mathrm{C}_{1}=-0.022, \mathrm{C}_{2}=5.218, \mathrm{C}_{3}=3.65, \mathrm{C}_{4}=-72.24 \\
& \mathrm{C}_{5}=4.65, \mathrm{C}_{6}=-0.226
\end{aligned}
$$

A value equal to $(0.86)$ for the determination coefficient $\left(R^{2}\right)$ has been found for the above formula that after arranging became:

$$
\mathrm{ds}_{\max } / \mathrm{y}=-0.022+\left\{5.218^{*}(\mathrm{v} / \mathrm{vc})^{3.65}\right\}-\left\{72.24^{*}\left(\mathrm{Fr}^{4.65}\right)\right\}-0.226^{*} \mathrm{n}
$$

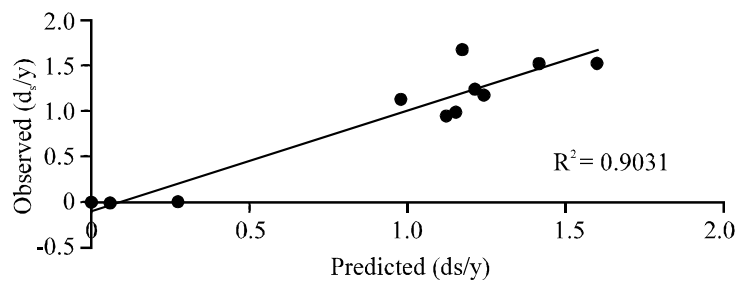

Fig. 14: Comparison of the experimental data with Eq. 4

The accuracy of this formula was tested using (20\%) of the original data that did not used in deriving it, that done by substituting the (20\%) data in the formula itself and then a statistical comparison is made between the predicted values of $\mathrm{d}_{s} / \mathrm{y}$ from the formula and the observed values from the experiments. A good agreement for all data is turn out when the value of determination coefficient is found to be $\left(\mathrm{R}^{2}=0.9031\right)$ as illustrated in Fig. 14.

\section{CONCLUSION}

The following conclusions are drawn from the present study based on the previous experimental work analysis: the scour process follows the same behavior for the I- \& C-shape when they tested under the same hydraulic conditions. The maximum scour depth in $\mathrm{C}$-shape groynes is less than that of I-shape groynes where that means more stability for groynes structure and more protection to the banks. At constant groynes number and spacing between them, increasing the flow depth, flow velocity and Froude number lead to increase the scour depth around the groynes.

When the hydraulic conditions are held constant, the depth of scour decrease with increasing the groynes number by about (47.6-66.7\%) for each increasing in groyne's number equal to one. The maximum scour depth was observed to occur at the upstream side of the 
groyne's nose. Due to it's location as a first groyne that water collide with then it is found that the maximum scour depth is taken place at the nose of this first groyne.

\section{THE LIST OF NOTATIONS}

$\mathrm{B}=$ The width of flume (L)

$\mathrm{b}=$ The distance between groynes $(\mathrm{L})$

$\mathrm{ds}=$ The local scour around groynes (L)

$\mathrm{d}_{50}=$ The main diameter of the sediment particle (L)

$\mathrm{Fr}=$ Froude number $(\mathrm{Fr}=\mathrm{V} / \sqrt{\mathrm{g}} \mathrm{y})(-)$

$\mathrm{g}=$ The gravitational acceleration $\left(\mathrm{LT}^{-2}\right)$

$\mathrm{L}=$ The length of groyne (L)

$\mu=$ Dynamic viscosity of water $\left(\mathrm{MTL}^{-1}\right)$

$\mathrm{n}=$ The number of groynes (-)

$\rho=$ The water mass density $\left(\mathrm{ML}^{-3}\right)$

$\rho_{\mathrm{s}}=$ The sediment mass density $\left(\mathrm{ML}^{-3}\right)$

$\mathrm{S}=$ The slope of flume (-)

$\mathrm{v}=$ The mean velocity of the flow $\left(\mathrm{LT}^{-1}\right)$

$\mathrm{vc}=$ The critical velocity $\left(\mathrm{LT}^{-1}\right)$

$\mathrm{y}=$ The flow depth (L)

$\sigma_{\mathrm{g}}=$ The geometric standard deviation of sand bed (-)

\section{ACKNOWLEDGEMENTS}

First of all, many thanks and praise are devoutly offered to my Creator, the Almighty Allah. I would like to express my sincere appreciation and deepest thanks to the Faculty of Engineering of the University of Kufa, especially the Civil Engineering Department for their patience and for given time that I needed to complete this research. Also, I want to show my appreciation and respective thanks towards my beloved family for their continuous encouragement, inspiration, patience and great support throughout this research work. At last, my acknowledgements go to all those people who made possible to accomplish this study.

\section{REFERENCES}

Ahmad, M., 1953. Experiments on design and behavior of Spur Dikes. Proceedings of the International Conference on Hydraulics Convention, September 1-4, 1953, Minneapolis, Minnesota, pp: 145-159.

Barbhuiya, A.K. and S. Dey, 2003. Vortex flow field in a scour hole around abutments. Int. J. Sediment Res., 18: $310-325$.

Dehghani, A.A., H.M. Azamathulla, S.F.H. Najafi and S.A. Ayyoubzadeh, 2013. Local scouring around L-head groynes. J. Hydrol., 504: 125-131.

Gill, M.A., 1972. Erosion of sand beds around spur dikes. ASCE J. Hydraulic Div., 98: 1587-1602.

Jafari, B. and A. Masjedi, 2015. The effect of slot on scouring around spur dike at 180 degree bend. Adv. Environ. Bio., 9: 215-220.

Lagasse, P.F. and E.V. Richardson, 2001. ASCE compendium of stream stability and bridge scour papers. J. Hydr. Eng. ASCE, 127: 531-533.

Martin, D., 1995. Bioengineering techniques for streambank restoration-a review of central European practices. MSc Thesis, University of British Columbia.

Masjedi, A., M.S. Bejestan and A. Moradi, 2010. Experimental study on the time development of local scour at a spur dike in a 180 degree flume bend. J. Food Agric. Environ., 8: 904-907.

Melville, B.W., 1997. Pier and abutment scour-integrated approach. J. Hydraulic Eng., 123: 125-136.

Onda, S., T. Hosoda, I. Kimura and M. Iwata, 2007. Numerical simulation on local scouring around a spur dike using equilibrium and non-equilibrium sediment transport models. Proc. Hydraul. Eng., 51: 943-948.

Yossef, M.F. and H.J. de Vriend, 2010. Sediment exchange between a river and its groyne fields: Mobile-bed experiment. J. Hydraul. Eng., 139: 610-625. 